\title{
The Quality and Antioxidant Content of Salted Eggs Made By Addition of Bay Leave Crude Extract on the Salting Media
}

\author{
Kadek Karang Agustina ${ }^{1}$, Ida Ayu Putu Aselya Mardyawati ${ }^{2}$, I Ketut Suada ${ }^{1}$ \\ Department of Public Health, Faculty of Veterinary Medicine, Udayana University ${ }^{1}$ \\ DVM Student of The Faculty of Veterinary Medicine, Udayana University ${ }^{2}$ \\ Jl. PB. Sudirman, Denpasar Bali Indonesia, 80225. \\ Email: k.agustina@unud.ac.id
}

\begin{abstract}
This research aims to produce salted eggs with antioxidant content from bay leave extract. The study used a completely randomized design (CRD) in which there were 3 treatments, namely, control with $0 \%$ bay leaf extract, treatment 1 with adding $25 \%$ crude extract of bay leaves, and treatment 2 with a $50 \%$ addition of crude bay leaf extract. All treatments were pressed for 14 days before testing. The parameters observed in the study were the antioxidant capacity, albumin index, yolk index, and Haugh unit. The results show that the sated eggs with the different concentration of bay leave extract contain antioxidant $4.445 \%, 30.853 \%$, and $44.32 \%$ respectively, albumin index of treated eggs was lower than control, while Haugh unit of treated eggs was higher than control, and no differentiation of yolk index between the treatments. To conclude, the addition of bay leave crude extract can increase the value of salted eggs without disturbing the quality.
\end{abstract}

Keywords: antioxidant; bay leaves; quality; salted egg

\section{INTRODUCTION}

Salam plants (Syzygium polyanthum) are herbal plants that are very useful, besides being a mixture of spices, they can also be used as medicinal plants. Winarto [1] states that bay leaves have a chemical content, namely, flavonoids, and essential oils of $0.05 \%$ consis ting of eugenol and citral [2]. The content of Eugenia polyantha is an active ingredient that is thought to have pharmacological effects. Tannins and flavonoids are active ingredients that have anti-inflammatory and anti-microbial effects, while essential oils have analgesic effects [3]. Ethanol extract of salam leaf showed anti-fungal and anti-bacterial effects, while the methanol extract was anti-worm, especially in pine wood nematodes Bursaphelenchus xylophilus [4]. Algabri et al. [5] stated that bay leaf extract was effective in inhibiting the growth of E. coli and Staphylococcus aureus. Phenolic components contained in plants have the ability to reduce the important role in absorbing and neutralizing free radicals, and decomposition of peroxides known as anti-oxidant properties [6]

The body needs antioxidants that can help protect the body from being attacked by free radicals by reducing the effects of these compounds. Vitamins C and E have been widely used as antioxidants because they are safer and the side effects are smaller than synthetic antioxidants. Synthetic antioxidants such as BHA (butylhydrocyanisol) and BHT (butyl hydroxitoluen) have higher antioxidant activity compared to vitamin $\mathrm{C}$ and vitamin $\mathrm{E}$ but these synthesized antioxidants can cause carcinogenesis [7]. Antioxidants from plants can block oxidative damage through reduction of free radicals, forming chelates with catalytic metal compounds, and capturing oxygen. Therefore, it is necessary to explore natural antioxidants to get antioxidants with high levels of safety and activity.

Some efforts have been made to produce food products that have antioxidant content [8]. One of the common animal products consumed by the public is eggs, because they have complete nutritional value, availability is large and the price is relatively cheap [9]. Previous research reported that the processing of salted eggs with the addition of biological compounds has produced a salted egg product which has antioxidant content. Salted eggs made by adding mangosteen peel to the media are reported to have antioxidant activity [10].

Salted eggs are processed intact, where the salt content can inhibit the development of microorganisms and at the same time give a distinctive aroma so that eggs can be stored in a relatively longer time [11]. Duck eggs are generally used as salted eggs because they have large pores [10]. Murtidjo [12] suggested that salted duck eggs have the advantage of nutritional value of eggs that can be maintained for a relatively long time, the economic value of eggs increases, meets the consumer tastes of duckeggs and, is a marketing alternative besides fresh eggs. 
Based on the potential of the beneficial natural ingredients contained in bay leaves, then in this study, crude extract of bay leaves was used as an addition to the media for making salted eggs. With the hope that salted eggs produced have antioxidant content and good quality.

\section{RESEARCH METHODS}

\section{Research Design}

This study used a completely randomized design (CRD) in which there were 3 treatments, namely control with $0 \%$ bay leaf extract, treatment 1 with adding $25 \%$ crude extract of bay leaves, and treatment 2 with a $50 \%$ addition of crude bay leaf extract. All treatments were pressed for 14 days before testing. Each treatment uses 10 duck eggs with 1 day age. There are four parameters observed in this study, namely: antioxidant activity, albumin index, yolk index and Haugh unit.

\section{Duck eggs preparation}

The sample used in this study is 30 eggs. All eggs come from the same farm. The age of all eggs were 1 day. The eggs were cleaned by washing used a sponge by rubbing the eggshell. The aimwas to open the pores of the egg and facilitate the process of exchange of salt with egg fluids [10].

\section{Salting media preparation}

The base media for salting eggs was using water and salt with ratio 1:1 (1 Kg salt mixture in $1 \mathrm{~L}$ fresh water). Fresh bay leaves prepared. To obtain media with a content of $25 \%$ bay leaf extract, mixed salt water (basic media) and scoured bay leaves with a ratio of 4: 1 (added $750 \mathrm{gr}$ in 3 It media). While to obtain $50 \%$ extract of bay leaves, mixing was done with a ratio of 2:1 (added 1.5 in 3 lt media).

\section{Treatments}

A total of 3 treatment groups, each consisted of $10 \mathrm{eggs}$ prepared. All eggs were put into salting media until the entire surface was submerged. all eggs were allowed to stand for 14 days as a marinating process [8] and observations were made.

\section{Antioxidant analysis}

Analysis of antioxidant levels of salted eggs using the DPPH method refers to the publication of Gurav et al. [26]. The antioxidant activity of salted eggs were measured based on its ability to contribute $\mathrm{H}+$ ions in stabilizing DPPH radicals. $0.1 \mathrm{mM}$ of DPPH solution (1.1-diphenyl-2picryl-hydrazyl) in ethanol solution was prepared, and 0.1 $\mathrm{ml}$ of the solution was added to $3 \mathrm{ml}$ of salted egg which had been diluted. Thirty minutes later performed an examination on a spectrophotometer at absorbance of 517 $\mathrm{nm}$. Reactions that produce low absorbance indicate a high antioxidant ability in neutralizing free radicals [8]. The antioxidant capacity was calculated using the formula [13] $\%$ Antioxidant $=\frac{A o-A c}{A o} \times 100 \%$

Where: $\mathrm{Ao}=$ Control absorbance; $\mathrm{Ac}=$ Sample absorbance

\section{Egg Quality Measurement}

\section{Albumin index}

The egg albumin index was calculated by comparing the height and average diameter of the albumin

\section{Yolk index}

The egg yolk index was calculated by comparing the height and diameter of the yolk

\section{Haugh unit}

The formula for calculating the Haugh unit according to Monira et al. [14]:

Haugh unit $(\mathrm{HU})=100 * \log \left(\mathrm{h}-1.7 \mathrm{w}^{0.37}+7.6\right)$

Where: $\mathrm{HU}=$ Haugh unit; $\mathrm{h}=$ observed height of the albumen in millimeters; $w=$ weight of egg in grams

\section{Data Analysis}

The results of the research data were analyzed by variance, if there were significant results, then it was followed by the Duncan Test to find out different parameters.

\section{RESULTS AND DISCUSSION}

Analysis of the results of antioxidant activity in salted eggs produced using media added to the crude extract of bay leaves at several concentrations is shown in table 1 .

TABLE 1

THE ANTIOXIDANT CAPACITY OF SALTED EGGS

\begin{tabular}{cc}
\hline $\begin{array}{c}\text { Bay leaves } \\
\text { concentration }\end{array}$ & $\begin{array}{c}\text { Mean of antioxidant } \\
\text { capacity } \%\end{array}$ \\
\hline $0 \%$ & 4.445 \\
$25 \%$ & 30.853 \\
$50 \%$ & 44.32 \\
\hline
\end{tabular}

These data in Table 1 proved that the antioxidant contained in bay leaves entered the eggs during salting period. The mechanism of salting process is an osmotic diffusion, where removal of water from lower concentration of solute to higher concentration through semi permeable membrane [15]. Salt that mixed to bay leaves extract will replace the water content of eggs. Antioxidant levels in salted eggs correlate with the concentration of bay leaf extract in a salt mixture. This data is in accordance with the research published by Agustina et al. [10] that found the antioxidant level in salted eggs 
created by the addition of mangosteen rind extract in the salted mixture.

The eggs albumin index obtained in this study showed significant results in variance analysis test, followed by Duncan test presented in Table 2.

TABLE 2

DUNCAN TEST RESULTS OF ALBUMIN INDEX OF SALTED EGGS

\begin{tabular}{ccc}
\hline $\begin{array}{c}\text { Bay leaves } \\
\text { concentration }\end{array}$ & $\begin{array}{c}\text { Mean of albumin } \\
\text { index }\end{array}$ & Sig. 0.05 \\
\hline $0 \%$ & 0.033 & $\mathrm{a}$ \\
$25 \%$ & 0.053 & $\mathrm{~b}$ \\
$50 \%$ & 0.060 & $\mathrm{~b}$ \\
\hline
\end{tabular}

According to Duncan test result in table 2, it is known that mean albumin index of salted eggs made by salted media with bay leaves extract have higher albumin index $(\mathrm{P}<0.05)$. The results of this study support previous publications reported by Kusuma et al. [16] which reported that the salted egg albumin index value on curing day 8 was 0.060 . Similar results were also reported by Tarigan and Agustina [17] where the value of salted egg albumin index on salt marinated day 7 and day 14 was 0.067 and 0.052 . The albumin index in both salted and non-marinated eggs will decrease due to the physio-chemical nature of the eggs losing $\mathrm{CO}_{2}$ through the skin pores of the albumin undergoing physical and chemical changes [18]. This is due to an increase in albumin $\mathrm{pH}$ which causes interactions between lysozyme and ovomucin which results in increased degradation of ovomucin [19].

The eggs yolk index obtained in this study showed no significant results in variance analysis test. The mean of yolk index is presenting in Table 3.

TABLE 3

DUNCAN TEST RESULTSOF MEAN YOLK INDEX OF SALTED EGG

\begin{tabular}{ccc}
\hline $\begin{array}{c}\text { Bay leaves } \\
\text { concentration }\end{array}$ & $\begin{array}{c}\text { Mean of yolk } \\
\text { index }\end{array}$ & Sig. 0.05 \\
\hline $0 \%$ & 0.829 & a \\
$25 \%$ & 0.833 & a \\
$50 \%$ & 0.871 & a \\
\hline
\end{tabular}

The Duncan test result (Table 3) showed no differentiation of yolk index between different bay leaves extract concentration in salting mixture $(\mathrm{P}>0.05)$. The results of this study were no different fromprevious studies which added mangosteen rind extract to egg marinating media, where the yolk index value was not affected by the addition of mangosteen extracts to the marinating media [8]. In addition, no different yolk index value was also reported in normal salted eggs with range of 0.830 to 0.850 [16],[17]. Egg yolks contain high value of fat, which is $50 \%$ of the solid material, which consists of $1 / 3$ protein and $2 / 3$ fat [20]. Generally, the yolk is round yellow or orange, is located at the center of the egg and is elastic [21]. The yellow color is mostly caused by dyes originating from the feed given, the higher the content of this pigment the more yellow the yolk color [22].

The eggs Haugh unit obtained in this study showed significant results in variance analysis test, followed by Duncan test is presenting in Table 4.

TABLE 4

DUNCAN TEST RESULTS OF HAUGH UNIT OF SALTED EGGS

\begin{tabular}{ccc}
\hline $\begin{array}{c}\text { Bay leaves } \\
\text { concentration }\end{array}$ & $\begin{array}{c}\text { Mean of Haugh } \\
\text { unit }\end{array}$ & Sig. 0.05 \\
\hline $0 \%$ & 33 & a \\
$25 \%$ & 44 & b \\
$50 \%$ & 47 & b \\
\hline
\end{tabular}

The Haugh unit is a measure of egg protein quality based on the height of its egg white [14]. In this research, the addition of bay leaves extract in salting mixture increased the mean of Haugh unit $(\mathrm{P}<0.05)$. The vitellin membrane is one of the most important parts of the yolk during the salting process because it pushes water out of the yolk and prevents water from entering, pushing $\mathrm{NaCl}$ into the yolk and preventing $\mathrm{NaCl}$ from coming out [23]. Egg structure based on Stadelman and Cotteril [24], shows the layers in the egg, so that in salted eggs salt will gradually enter from albumin to yolk. Egg weight will decrease during storage period. The $\mathrm{pH}$ value of albumin will increase if it is stored longer, causing physical and chemical damage. Haugh unit value will also decrease if the weight of the egg and height of egg white decreases [25]. While marinated period of salted duck eggs is longer, the Haugh unit value will increase. This is due to the level of salt that goes into the egg white and duration of storage [17].

\section{CONCLUSION}

To conclude, salted eggs which produced by adding of bay leaves extract to salting mixture have a capacity of antioxidant. The quality of salted eggs is not different to normal salted eggs, while albumin index and Haugh unit values were increased to $0.053-0.060$ and $44-47$ respectively.

\section{ACKNOWLEDGEMENT}

Thanks to The Rector of Udayana University through The Dean of The Faculty of Veterinary Medicine Udayana University to facilitated this research.

\section{REFERENCES}

[1] Winarto WP. 2004, Memanfaatkan Bumbu Dapur untukMengatasi Aneka Penyakit. Jakarta: Agromedia Pustaka.

[2] Dalimartha S. 2000. Atlas Tubuhan Indonesia, 2th Ed, 162-165, Trubus Agriwidya, Jakarta.

[3] Robinson T. 1995. Kandungan Organik Tumbuhan Tinggi. Bandung: IT B.

[4] deGuzman CC, Siemonsma JS. 1999. Plant Resources ofSouthEast Asia 13: Spices. PROSEA. Bogor. 
[5] Algabri SO, Doro BM, Abadi AM, Shiba MA, Salem AH. 2018. Bay Leaves have antimicrobial and antioxidant activity. JPatogh Res. 1(1): 1-5.

[6] Javanmardi J, Stushnoff C, Lockeb E, Vivanedo JM. 2003. Antioxidant activity and Total Phenolic content of Iranion Ocimum accessions. J Food Chem, 83: 547-550.

[7] Kikuzaki H, Hisamoto M, Hirose K, Akiyama K, Taniguchi H. 2002. Antioxidants Properties of Ferulic Acid and Its Related Compound. J Agric Food Chem, 50: 2161-2168.

[8] Agustina KK, Dharmayudha AAGO, 2015. Pemanfaatankulit buah manggis sebagai media pembuatan telur asin. Majalah Ilmiah Peternakan, 18(3): 114-118.

[9] Ledvinka Z, Zita L, Klesalová L. 2012. Egg quality and some factors influencing it: a review. Sci Agric Bohem, 43(1): 46-52.

[10] Agustina KK, Dharmayudha AAGO, Swacita IBN, Sudimartini LM. 2015. Analisis Nilai gizi telur itik asin yang dibuat dengan media kulit buah manggis (Garcinia mangostana L) selama masa pemeraman. Buletin Veteriner Udayana, 7(2): 113-119.

[11] Wang ZF, Dai C, Wang T Y. 2017. A simple method to evaluateoil in salted egg. Int J Food Prop. 20(2): 1816-1822.

[12] Murtidjo BA. 1988. Mengelola Itik. Kanisius, Yokyakarta.

[13] Lailiyah A, Adi TK, Hakim A, Yusnawan E. 2014. Kapasitas antioksidan dan kandungan total senyawa fenolik ekstrakkasaralga coklat Sargassum cristaefolium dari pantai sumenep madura. Alchemy, 3(1): 18-30.

[14] Monira KN, Salahuddin M, Miah G. 2003. Effect of Breed and Holding Period on Egg Quality Characterist ics of Chicken. Int J Poult Sci, 2(4): 261-263.
[15] Yadav AK, Singh SV. 2014. Osmotic dehydration of fruits and vegetables: a review. J Food Sci Technol. 51(9): 1654-1673.

[16] Kusuma E, Ruddyanto MD, Suada IK. 2012 Pengasinan Mempengaruhi Kualitas Telur Itik Mojosari, Indo Med Vet. 1(5): 645-656.

[17] Tarigan RLB, Agustina KK. 2016. Kualitas telur asin bermediakulit manggis (Garcinia mangost ana L) berdasarkan Indeks Put ihTelur, Kuning Telur, dan Haugh Unit. Indo Med Vet. 5(1): 30-37.

[18] Tien R, Sugiono M, Ayustaningsih F. 2010. Ilmu Pengetahuan Bahan Pangan. Cetakan Kedua. Alfabeta.

[19] Singh RP, Panda B. 1990. Comparative study on some quality at tributes of quail and chicken eggs during storage. Indian J Anim Sci. 60: 114-117.

[20] Belitz HD, Grosch W. 1999. Food Chemistry. Spinger, Germany.

[21] Winarto FG, Koswara S. 2002. Telur: Komposisi, Penanganandan Pengolahannya. M-Brio Press. Bogor.

[22] Winarto FG. 1993. Pangan Gizi, Teknologi dan Konsumen.Jakarta: Gramedia Pustaka Utama.

[23] Romanoff AL, Romanoff A. 1963. The Avian Egg.John Wiley and Sons, New York.

[24] Stadelman WJ, Cotteril OJ. 1977. Egg Science and Technology. The AVIPublishing, Inc. Westport. Connecticut.

[25] Roesdiyanto. 2002. Kualitas telur itik tegal yang dipelihara secara intensif dengan berbagai tingkat kombinasi Metionin-Lancang (Atlanta Sp). J Anim Prod. 4(2): 77-82.

[26] Gurav SS, Deshkar NS, Tilloo SK, Duragkar NJ, Burade K. 2013. Antimicrobial and antioxidant evaluation of Flacourtia Ramontchi L. Herit. J Herbs Spices Med Plants. 19(1): 76-95. 